\title{
Using numerical models and acoustic methods to predict reservoir sedimentation
}

\section{Şebnem Elçi , Aslı Bor \& Anıl Çalışkan}

To cite this article: Şebnem Elçi , Aslı Bor \& Anıl Çalışkan (2009) Using numerical models and acoustic methods to predict reservoir sedimentation, Lake and Reservoir Management, 25:3, 297-306, DOI: 10.1080/07438140903117183

To link to this article: http://dx.doi.org/10.1080/07438140903117183

册 Published online: 14 Sep 2009.

Submit your article to this journal $\pi$

Џ Article views: 240

Q View related articles $\widetilde{ }$

Citing articles: 5 View citing articles 5 


\title{
Using numerical models and acoustic methods to predict reservoir sedimentation
}

\author{
Şebnem Elçi*, Aslı Bor, and Anıl Çalışkan \\ Department of Civil Engineering, Izmir Institute of Technology, Urla, Izmir, Turkey
}

\begin{abstract}
Ş. Elçi, A. Bor, and A. Çalışkan 2009. Using numerical models and acoustic methods to predict reservoir sedimentation. Lake Reserv. Manage. 25:297-306.

This study draws on drainage basin hydrography, numerical modeling and geographic information system (GIS) techniques in concert with dual frequency echo sounder data to estimate sediment thickness when initial surveys are unavailable or inaccurate. Tahtali Reservoir (Turkey), which provides $40 \%$ of water supply to the city of Izmir, was selected as the study site. Deposition patterns within the whole lake were estimated with a 3-D hydrodynamic and sediment transport model applied to Tahtali Reservoir. The numerical model simulated lake response to wind forcing and inflows and/or outflows and was used to describe sediment deposition patterns resulting from the erosion of soils quantified by the implementation of Universal Soil Loss Equation (USLE) to the whole watershed. Surveying of the lake via dual frequency $(28 / 200 \mathrm{kHz})$ echo sounder system revealed the current bathymetry, and sediment thickness was estimated from the difference of depths measured by the dual frequency sounder along surveyed transects. These results were compared to the modeled sedimentation thicknesses and to preliminary estimates of watershed sediment yield estimated by USLE. Results of this study can be used for further water quality studies and for long term management plans.
\end{abstract}

Key words: bathymetry, echo sounder, EFDC model, sedimentation, Tahtali Reservoir, USLE

Sustainable management of soil and water resources is one of the critical environmental issues facing many countries, particularly developing countries. Management issues include water supply, water quality, flood control, soil erosion, irrigation, tourism, reservoir management and fishing. Of these issues, soil erosion causes the greatest environmental deterioration through both on-site (with the loss of fertile soil) and off-site (by deposition of eroded sediments) effects. Some of the sediment transported within a watershed is deposited in the reservoir due to stagnant water velocity in the lakes, reducing its lifetime and the hydrodynamic potential of dams. These sediments might also carry pollutants and lead to contamination of drinking water supplies. Reduction in storage capacity has impacts on the function of the reservoir's purpose and results in notable costs to the regional economy. Accurate prediction of sedimentation is required for better design and operation of reservoirs (Graf 1984, Fan and Morris 1992).

*Corresponding author: sebnemelci@iyte.edu.tr
Reservoir sedimentation has been widely studied in the past, often focusing on the description and investigation of the mechanism that transports sediments into the reservoir (Guy et al. 1966, Soni 1981, Blumberg and Mellor 1987, Falconer et al. 1991, Hotchkiss and Parker 1991, Blumberg et al. 1999, Jin et al. 2000, Yang et al. 2000, Rueda and Schladow 2003, Elçi et al. 2007). Deposition rates were of primary interest in many studies and were modeled numerically (Jin et al. 2000, Rueda and Schladow 2003, Elci et al. 2007) or measured via surveying (Snyder et al. 2006, Pratson et al. 2008). Recently, Pratson et al. (2008) surveyed Lake Powell, United States, and compared the survey results to the previous surveys conducted within the lake to estimate accumulation rates. They observed shifting of deposition from delta foresets to the deeper parts of the lake during dry periods. Snyder et al. (2006) related reservoir stratigraphy measured through coring to flood history of a reservoir in California and inferred that most of the fine sand at the bottom was deposited during floods.

Surveying of reservoirs is required to determine sedimentation rates and to assess the overall capacity of the reservoir. The use of echo sounders has dramatically improved 
data quality and quantity, but state of the art surveying has not changed much since earlier times when water depth was measured manually using sounding lines (rope with a weight at the end) where measurements were conducted by following cables stretched across the reservoirs. For reasons of economy and expediency, these measurements were limited to 5-10 point measurements along transects selected several kilometers apart. With the current developments in multibeam technology and global positioning system (GPS) satellite navigation, faster, more accurate and continuous surveying of transects is possible (Pratson et al. 2008). Technical details of scanning and sediment mapping are discussed by Urick (1983). Besides the detailed and accurate bathymetry data obtained from multi-frequency echo sounders, subbottom profiles also provide estimates of sediment thickness underlying the water column (Collins et al. 1996, Dunbar et al. 2002, Odhiambo and Boss 2004).

In this study we conducted hydrographic surveying in a reservoir located in Turkey using a dual frequency (28/200 $\mathrm{kHz}$ ) echo sounder system and GPS navigation. The applicability of dual frequency echo sounders for prediction of sedimentation thickness when initial surveys are unavailable or inaccurate was investigated along surveyed transects. Surveying the lake with a dual frequency sounder provided sediment thickness information only along the surveyed transects; hence, a numerical hydrodynamic model was used to predict deposition patterns within the whole lake. The complexities of the hydrodynamic processes in this reservoir required the use of numerical modeling approaches to provide a description of circulation, mixing and density stratification.

We applied a numerical hydrodynamic model to Tahtali Reservoir to simulate lake response to wind forcing and inflows and/or outflows and to describe sediment deposition patterns resulting from the erosion of soils in the watershed. Sedimentation patterns were estimated and also compared to preliminary estimates of watershed sediment yield obtained from the implementation of Universal Soil Loss Equation (USLE) to the studied basin. The Environmental Fluid Dynamics Code (EFDC) developed by Hamrick (1996) was selected for this purpose. Sediment thicknesses along the transects simulated by the numerical model were compared with the sediment thicknesses estimated from the surveying of the lake by dual frequency echo sounder.

\section{Materials and methods}

\section{Study site}

Observations were conducted in Tahtali Reservoir (Fig. 1) Izmir, Turkey. Tahtali Dam, completed in 1996 and filled in 1998, was projected as a rock-fill dam to supply fresh

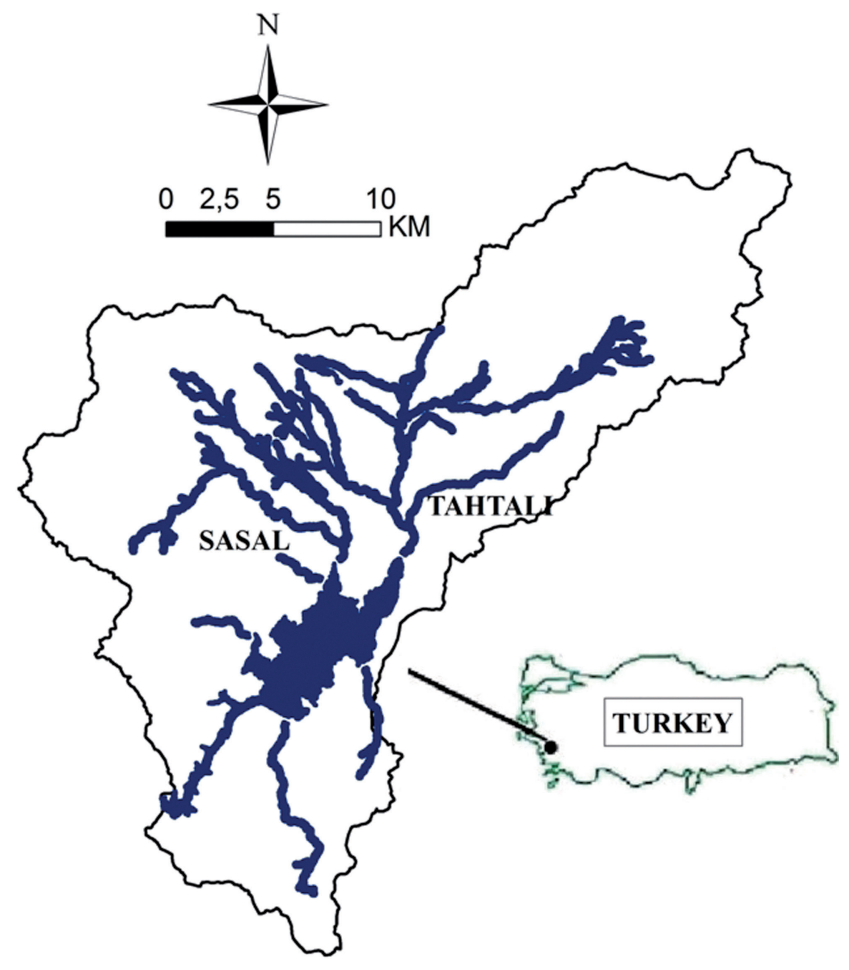

Figure 1.-Location of study area: Tahtali Basin.

water to Izmir, the third largest metropolitan area in Turkey with more than 3 million people. The capacity of the dam is $175 \times 10^{6} \mathrm{~m}^{3}$ and it supplies $5 \times 10^{6} \mathrm{~m}^{3}$ of water per month. The dam is currently operated by the Izmir Water and Sewage Administration (IZSU).

Tahtali Basin covers approximately $550 \mathrm{~km}^{2}$. The reservoir has a surface area of $20 \mathrm{~km}^{2}$, a mean depth of $15 \mathrm{~m}$ and a maximum depth of $27 \mathrm{~m}$ (when the water level was $60 \mathrm{~m}$ a.s.l.). The major inflows are from the north via Şaşal and Tahtali streams, which contribute $25 \%$ and $75 \%$, respectively, to the total inflow. These streams merge into one river at the main pool (Fig. 1). The discharges of 4 other streams are negligible. The withdrawal point is at the southwest end of the lake from the deepest area corresponding to $27 \mathrm{~m}$. The water is treated and used as drinking water in the city of Izmir (Çalışkan and Elçi 2008).

\section{Prediction of erosion by USLE}

For quantification of soil loss within the watershed, soil and topographic maps of the basin were constructed into a vector-type spatial database using GIS and 1:5000 scale topographic maps provided by IZSU and 1:25,000 scale soil maps showing soil types and land usage in 1995 from General Directorate of Rural Services. To predict soil erosion we implemented USLE, widely used throughout the world in different studies to estimate average soil loss due to splash, 
sheet and rill erosion caused by raindrop impact and surface runoff (Wischmeier and Smith 1978). After advances in GIS techniques, USLE was often implemented together with GIS because of its efficiency at managing and analyzing data (Golson et al. 2000, Lee 2004, Odhiambo and Boss 2004). USLE predicts the long term average annual erosion rate on a field slope based on the rainfall regime, soil type, cropping system and management practices, factors extracted from the spatial database.

The average annual soil erosion rate was calculated for Tahtali Basin using a USLE method that considers 6 factors with values that can be specified numerically for a given location:

$$
A=R K L S C P
$$

where; $A$ is the average annual soil loss in ton/ha/year; $R$ is the rainfall erosivity factor in mega joule (MJ)$\mathrm{mm} / \mathrm{h} / \mathrm{ha} /$ year representing the annual sum of the products between the energy of the erosive rainfalls in $\mathrm{MJ} / \mathrm{ha}$ and their intensity in $\mathrm{mm} / \mathrm{h} ; K$ is the soil erodibility factor in ton-h/MJ/mm; $L$ is the slope length factor (unitless); $S$ is the slope steepness factor (unitless); $C$ is the cropping management factor (unitless); and $P$ is the supporting practice factor (unitless).

Rain erosivity factor was calculated with respect to 8-32 years of data collected at 96 different weather stations in Turkey (Doğan 2002). The average annual $R$ value calculated for Izmir $(\mathrm{R}=166)$ was used to predict the soil erosion in Tahtali Basin. The distribution of monthly calculated $R$ values for Izmir (Table 1) shows that, as expected, rain erosivity factors are higher in winter.

The soil erodibility factor represents the average long term soil response to erosion by rainfall/runoff and varies with soil characteristics. The infiltration rates vary between zero and one, where higher $\mathrm{K}$ values indicate that soil is more sensitive to erosion. In general, erosion is very low to none in alluvial soil types, low or medium in colluvial soil types, and high in soils including silt and iron in their structure. The soil erodibility map of the basin with different soil types (Fig. 2) used K values for different soil types: 0.15 for low to nonerosive; 0.28 for moderately erosive; 0.45 for highly erosive; and 0.60 for very highly erosive soils.

Erosion-prone areas were determined from the erodibility map of the watershed. According to this classification, 17\% of the basin area is subject to very high erosion, $42 \%$ is subject to high erosion, and erosive soils are located close to the lake.

Slope length is the horizontal distance along the flow path from the origin of the overland flow to the deposition point. As the slope length increases, erosion rate increases. Different equations are available for calculation of slope length factor (L). For this study we used (McCool et al. 1989):

$$
L=(I / 22.1)^{0.5}
$$

where; $I$ is the slope length in (feet).

The slope steepness factor, $\mathrm{S}$, represents the effect of slope on soil erosion. If the slope of the land is high, more erosion occurs in the area. Slope steepness factor affects the rate of erosion more than the slope length. In the analysis, distributed slope values for each polygon were calculated and implemented in the USLE equation.

The crop management factor represents the effect of cropping and management practices on soil erosion and reflects how the vegetal cover absorbs the energy of rain. The vegetal cover can reduce the drop size and provides mechanical protection by increasing the infiltration capacity of soil. The Tahtali Basin has different land uses (Fig. 3) but is mainly covered by forests $(35 \%)$ and heath bell $(31 \%)$. Undisturbed forests provide the best soil protection, whereas heath bell lands are considered highly erosive. Erosion of soils is highest in fallow lands (10\% of basin area) where the crop management factor is set to 1 .

The supporting practice factor represents the effects of practices including terracing contouring, silt fences and subsurface drainage. The average practice factor for Menemen/Izmir was 0.44 (ranged between 0.10 and 0.92 ) as provided by Oguz et al. (2006)

Maps obtained from the General Directorate of Rural Services showing soil types and land usage were composed of 245 polygons representing different land uses and soil types in the basin (Fig. 3). The annual soil erosion loss for each polygon was calculated, and comparisons were made (Table 2) of the factors used in the analysis for 2 different polygons (Fig. 2). For instance, for polygon number 235 the crop type is forest $(\mathrm{C}=0.001)$, whereas in polygon number 146 the crop type is tillage with a very high cropping management factor $(\mathrm{C}=0.48)$. Considering

Table 1.-Distribution of rain erosivity factors $(R)$ measured in Izmir-Menderes over 20 years measured data.

\begin{tabular}{lcccccccccccc}
\hline & Jan & Feb & Mar & Apr & May & Jun & Jul & Aug & Sep & Oct & Nov & Dec \\
\hline R (t-m/ha) & 19.17 & 16.69 & 18.08 & 7.03 & 7.85 & 2.34 & 0.86 & 0.87 & 4.20 & 22.66 & 26.76 & 37.05 \\
\hline
\end{tabular}




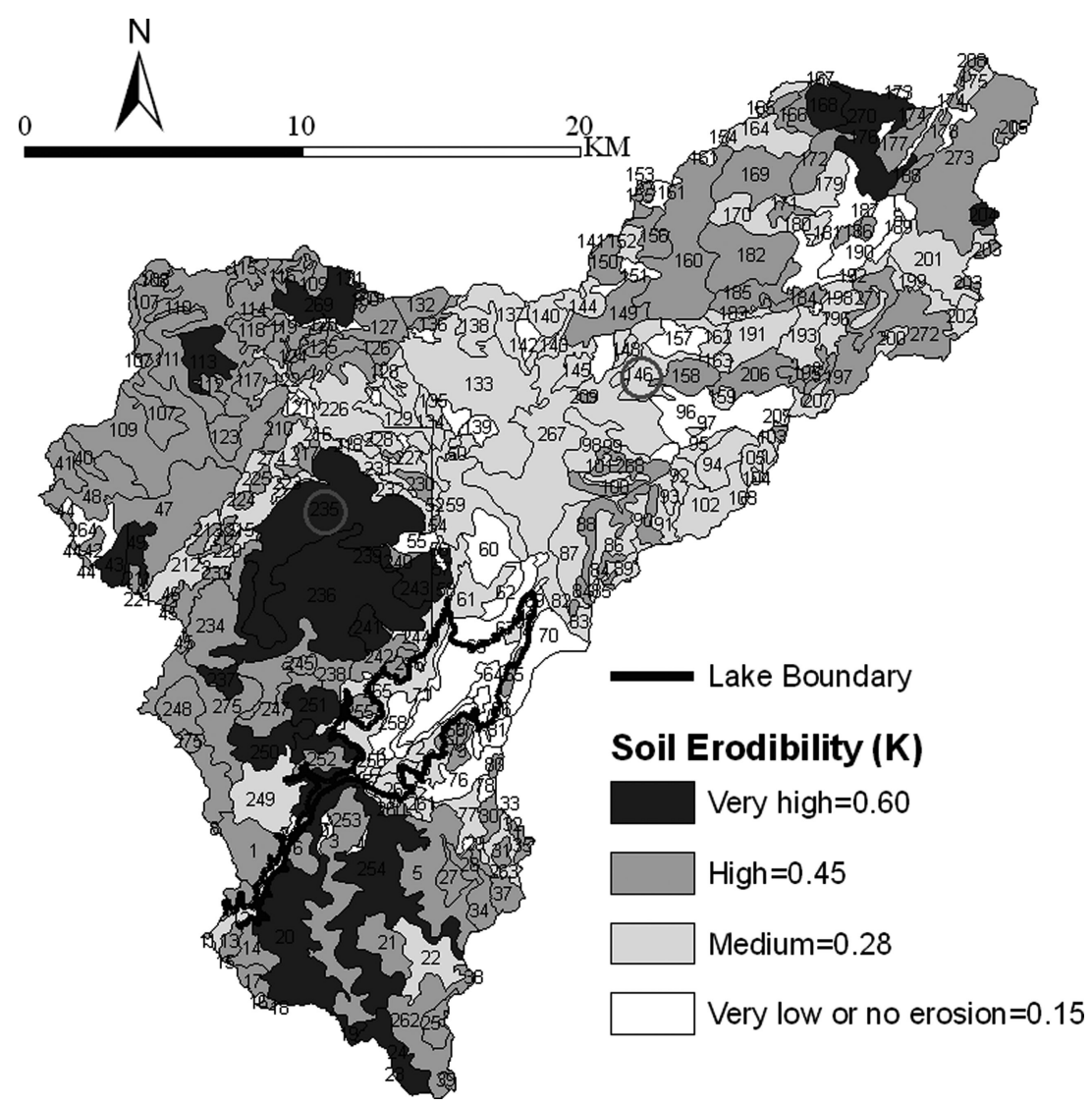

Figure 2.-Chorophlet map of Tahtali Basin showing erosion types of the polygon layers.

the factors mentioned above for the analysis, Eq.1 was applied and the erosion rates of the soils in polygons 235 and 146 were calculated as 0.265 and 16.9 ton/ha/year, respectively. The steps summarized for two polygons (235 and 146) were repeated for 245 polygons, and the soil loss was estimated as $224 \times 10^{6}$ tons for 9 years since the filling of the reservoir.

\section{Modeling of sediment deposition}

In this study, EFDC was used to model the hydrodynamics and sedimentation in Tahtali Reservoir. EFDC is a generalpurpose modeling package for simulating three-dimensional

Table 2.-Calculation of erosion rate by USLE method for two polygon layers.

\begin{tabular}{lcccccccc}
\hline & $\begin{array}{c}\text { Land } \\
\text { Object }\end{array}$ & $\begin{array}{c}\text { A } \\
(\mathbf{t} / \mathbf{h a} / \mathbf{y e a r})\end{array}$ & $\mathbf{R}$ & $\mathbf{K}$ & $\mathbf{L}$ & $\mathbf{S}$ & $\mathbf{C}$ & $\mathbf{P}$ \\
\hline 146 & Tillage & 16.913 & 166 & 0.28 & 17.229 & 0.10 & 0.480 & 0.44 \\
235 & Forest & 0.265 & 166 & 0.60 & 24.206 & 0.25 & 0.001 & 0.44 \\
\hline
\end{tabular}

(3-D) flow, transport and biogeochemical processes in surface water systems such as rivers, lakes, reservoirs, estuaries, wetlands and coastal regions (Hamrick 1996). In addition to hydrodynamics, salinity and temperature transport simulation capabilities, EFDC is capable of simulating cohesive and noncohesive sediment transport, near-field and far-field discharge dilution from multiple sources, and the transport and fate of toxic contaminants in the water and sediment phases. The model uses a finite difference scheme based on hydrostatic hydrodynamic equations and transport equations in vertical and horizontal coordinate systems that may be Cartesian or curvilinear-orthogonal. Various finite difference numerical schemes are available for the solution of the equations. The model can also simulate wetting and drying conditions of the grid cells. The model has been applied to several water systems (Shen and Kuo 1999, Tetra Tech Inc. 1999, Jin et al. 2000, 2002, Jin and Ji 2002, Elçi et al. 2007, Çalışkan and Elçi 2009). A detailed description of EFDC is provided in Hamrick (1996).

The Tahtali hydrodynamic model grid contains 6084 cells, 2041 of which were active horizontal curvilinear grid 


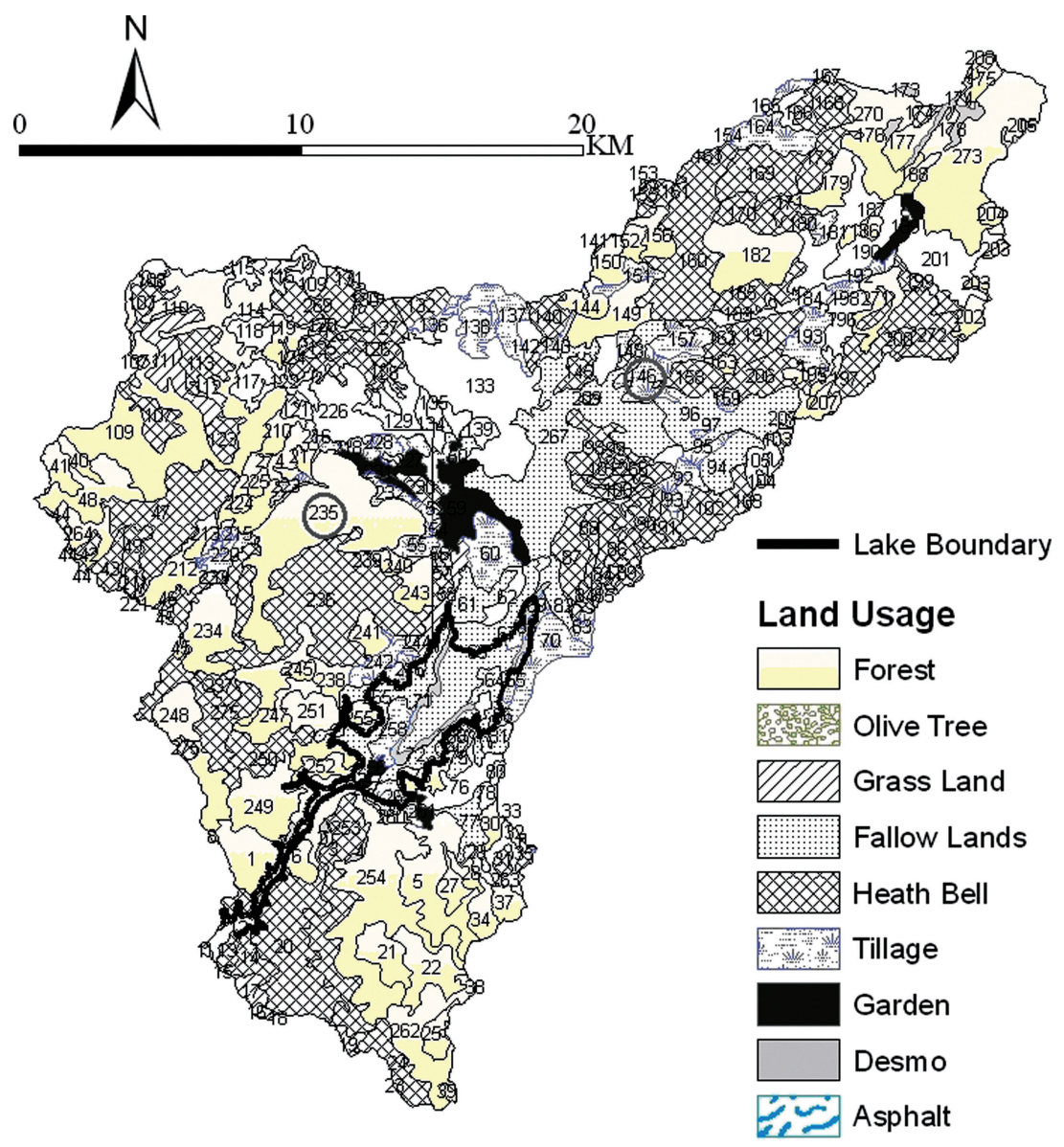

Figure 3.-Chorophlet map of Tahtali Basin showing the land usages.

cells with 7 vertical layers. The time step used for the model was $10 \mathrm{sec}$ to insure numerical stability. The horizontal discretization of each computational cell $\left(D_{x}, D_{y}\right)$ was $100 \mathrm{~m}$ on a side. The typical initial average water depth in each grid ranged from $1 \mathrm{~m}$ in the shallow region to $27 \mathrm{~m}$ in the deepest region. The dimensionless vertical layer thicknesses used in simulations were tabulated (Table 3). The inflows were specified in the model based on historical discharge data measured in Derebogazi where Tahtali and Şaşal streams merge and based on the few measurements made by the authors at Tahtali and Şaşal streams.

Accurate quantification of sedimentation by a numerical model depends mainly on correct specification of sediment input to the model. However, neither a sediment rating curve derived from long term measurements of sediment concentrations nor direct long term measurements were available for the study site. The sediment concentrations at rivers specified as input to the model were based on the erosion loss predicted by the USLE approach applied to Tahtali Basin as explained in the previous section.
The withdrawal rate obtained from IZSU was constant and equal to $3 \mathrm{~m}^{3} / \mathrm{s}$. The soil granulometry of rivers as determined from the collected samples was used to determine the sediment types simulated in the model. The mean diameter $\left(D_{50}\right)$ values of $0.03 \mathrm{~mm}$ for Tahtali and $0.02 \mathrm{~mm}$ for Şaşal were acquired from sieve and hydrometric analysis. Soil granulometry of the rivers indicated negligible concentration of noncohesive sediments. Constant initial suspended sediment concentration of the lake was defined based on the turbidity values measured by water quality meter and was specified as $15 \mathrm{mg} / \mathrm{L}$ at each layer of the water column (Elçi 2008). Constant sediment settling velocity was defined as 5 $\times 10^{-5} \mathrm{~m} / \mathrm{s}$ based on (Yang 1996):

$$
w=\frac{4}{9} \frac{\left(\gamma_{s}-\gamma_{w}\right)}{\gamma_{w}} g \frac{d^{2}}{v}
$$

where; $w$ is the settling velocity of depositing sediment; $\gamma_{s}$ is the specific weight of sediment; $\gamma_{w}$ is the specific weight of water; $g$ is the acceleration of gravity; $d$ is the mean diameter of sediment; $v$ and is the kinematic viscosity of water. 
Table 3.-Sediment transport parameters used in EFDC numerical model.

\begin{tabular}{lc}
\hline Model parameter & Value \\
\hline $\begin{array}{l}\text { SEDO: Constant initial cohesive sediment } \\
\text { concentration in water column }(\mathrm{mg} / \mathrm{L})\end{array}$ & 15 \\
$\begin{array}{l}\text { SEDBO: Constant initial cohesive sediment in bed } \\
\text { per unit area }\left(\mathrm{g} / \mathrm{m}^{2}\right)\end{array}$ & $1.193 \times 10^{5}$ \\
SDEN: Sediment specific volume $\left(\mathrm{m}^{3} / \mathrm{g}\right)$ & $4 \times 10^{-7}$ \\
SSG: Sediment specific gravity & 1.740 \\
WSEDO: Constant or reference sediment settling & $5 \times 10^{-5}$ \\
$\quad$ velocity $(\mathrm{m} / \mathrm{s})$ & \\
TAUD: Boundary stress below which deposition & $2 \times 10^{-4}$ \\
$\quad$ takes place $\left(\mathrm{m}^{2} / \mathrm{s}^{2}\right)$ & \\
TAUR: Boundary stress above which deposition & 0.013 \\
$\quad$ takes place $\left(\mathrm{m}^{2} / \mathrm{s}^{2}\right)$ & \\
WRSPO: Reference surface erosion rate $\left(\mathrm{g} / \mathrm{m}^{2} \mathrm{~s}\right)$ & 0.010 \\
\hline
\end{tabular}

The sediment transport parameters used in the simulations were summarized (Table 3).

\section{Bathymetry and sediment thickness measurements}

Bathymetric surveys of Tahtali Lake Reservoir conducted between August and September 2007, coinciding with a low lake level (46 m a.s.1.) after a dry period in 2007 (160 $\mathrm{mm}$ rainfall was one-third of rainfall observed in 2006). The type of echo sounder was selected mainly according to its ability to distinguish the bed surface. In dual frequency echo sounders, the results of depth measurements may differ in terms of frequency response of transducers in the detection of soft mud. A $320 \mathrm{~B} / \mathrm{P}$ dual frequency echo sounding system produced by Knudsen Engineering was used in the study.

The operating principle of an echo sounder is based on transmitting a ping and listening to the return of the echo; water depth is estimated by measuring the time for the transmitted ultrasound pulse to return. The high frequency $(200 \mathrm{kHz})$ sound wave tracks the top of the sediment, whereas the low frequency $(28 \mathrm{kHz})$ wave penetrates through the sediment to a more solid bottom. The advantage of using a dual frequency echo sounder is that sediment thickness can be estimated from the different echoes generated at the interface between water (low impedance) and sediment (high impedance) layers. The difference in high and low frequency channel depth readings gives the sediment thickness. Thus, a dual frequency system provides useful information about both sediment thickness and bathymetry.
Sediment deposits in a reservoir filled with water tend to be finer and have higher water content than the underlying sediment strata. This helps identification of different sediment layers. If the bottom type is rock, gravel or sand, the transducer will produce strong echoes. In contrast, weak echoes will be caused by mud or silt surfaces. A return darker in color would indicate a harder layer lying below the mud or silt layers (Fig. 4).

Aquatic vegetation may block the high frequency signal and cause the scattering of the signal off vegetation rather than the lake floor, a problem encountered in some of the shallower parts of Tahtali Reservoir that affected both high and low frequency signals. Echo sounder readings should be carefully interpreted in very shallow water with a solid bottom, where too much energy in the water may result in multiple echoes from the same bottom surface and erroneously interpreted as different sediment strata.

In echo sounders, repeatability, scale and offset are the possible error sources. Repeatability error results when, data measured sequentially have the same value. Scale error results when the constant sound speed provided by the user $(1500 \mathrm{~m} / \mathrm{s})$ varies with water temperature (5 C difference in water temperature results in $1 \%$ error) and with the medium penetrated (sound speed is $1530 \mathrm{~m} / \mathrm{s}$ for sand and $1430 \mathrm{~m} / \mathrm{s}$ for clay [Knudsen Engineering Ltd. 2005]). Offset error depends on the factory calibration of filters. The offset parameter is calibrated to zero at the factory to account for small time delays built into the signal paths in the echo sounder, by far the largest component of which is group delay through digital filters (Knudsen Engineering Ltd. 2005).

In this study, a $28 / 200 \mathrm{kHz}$ dual transducer was mounted on fiber glass pontoons attached to the side of the boat provided by IZSU. The depth readings of both frequencies were recorded to a laptop computer during the survey. The position coordinates were acquired using a Trimble Pathfinder Pro XRS GPS receiver with a horizontal position accuracy of $30 \mathrm{~cm}$. The GPS data were recorded every $5 \mathrm{sec}$ whereas echo sounder data were recorded every second. We measured12,642 soundings along a length of $16.4 \mathrm{~km}$ (Fig. 5). In addition to the real time correction navigation data obtained from GPS, data were filtered to have more than 3 satellites. The coordinate system used in the study was UTM 35 North Zone, WGS 1984 Datum. Before beginning the survey, the accuracy of the echo sounder was determined from continuous readings of a known depth $(5 \mathrm{~m})$ with a uniform temperature distribution as $\pm 5 \mathrm{~cm}$, meaning $1 \%$ accuracy in measurements. A constant sound speed of $1500 \mathrm{~m} / \mathrm{s}$ was used during the surveying of this thermally stratified lake where the temperature differences between surface and bottom reached $10 \mathrm{C}$, resulting in a $7 \%$ maximum error in depth readings. 


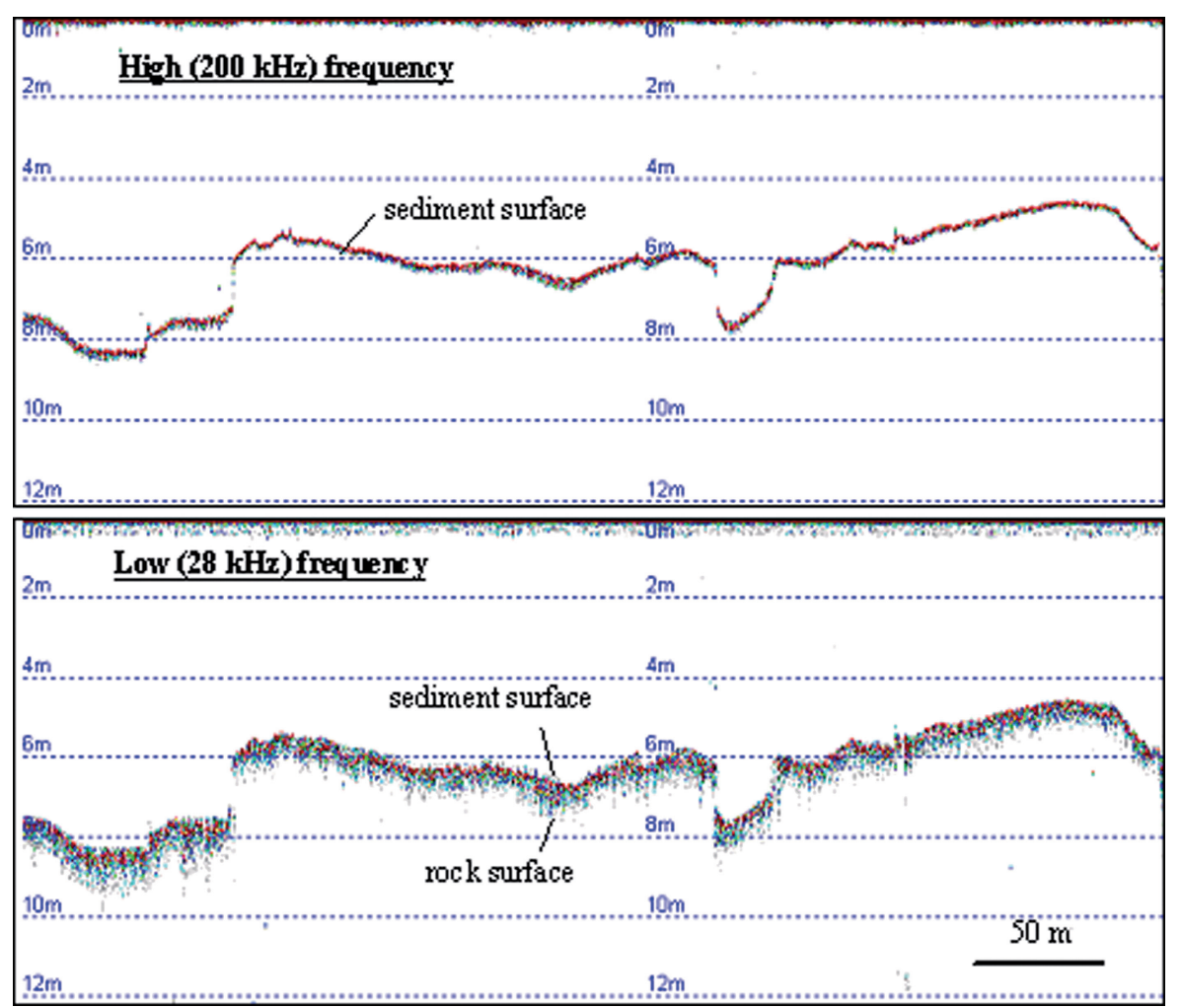

Figure 4.-Sample readings obtained from the echo sounders software for high (200 kHz) and low (28 kHz) frequency readings. Current bathymetry is identified in the high frequency readings.

\section{Results}

Bathymetric surveys of Tahtali reservoir revealed the current bathymetry of the lake and the sediment accumulation

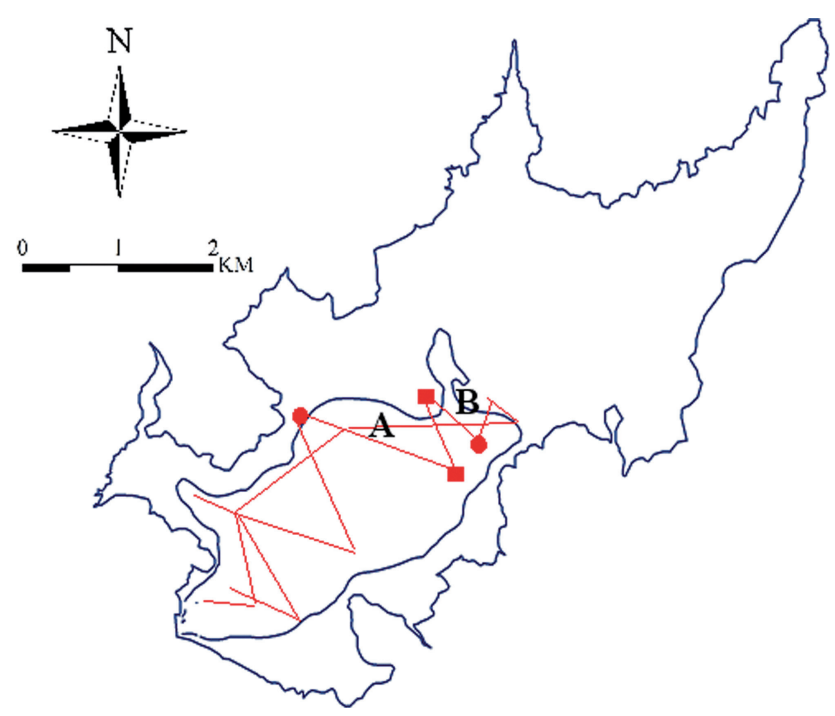

Figure 5.-Surveyed transects and transects of presented topographic profiles. Circles show the starting points and squares show the ending points of the transects. since the filling of the reservoir. At the time of the measurements, the average depth of the reservoir was $5 \mathrm{~m}$ and maximum depth was approximately $15 \mathrm{~m}$ where the rivers merge by the water intake. Due to a dry period before measurements, the lake level was $46 \mathrm{~m}$ a.s.l. compared to the operation level of $60 \mathrm{~m}$, and shallower regions were dry and could not be surveyed. We observed that water wells and local hollows located at the lake bottom before the filling of the lake were filled with sediments about $1 \mathrm{~m}$ thick (Fig. 6).

Deposition was calculated as $11 \times 10^{6}$ tons based on the spatial distribution of thickness and assuming density of sediment as $1.1415 \mathrm{~kg} / \mathrm{m}^{3}$ (derived from Verstraeten and Poesen 2000; sediment size $0.03 \mathrm{~mm}$ determined by sampling of lake bottom). The sediments were mostly deposited along the thalweg of the pre-impoundment river bed with an average thickness of $25 \mathrm{~cm}$, while deposition on the reservoir floor was less on either side of the thalweg. In the downstream parts of the lake close to the dam sediment thickness was generally uniform, whereas in the upstream parts variations were observed. The eastern region of the lake sloped gently, and small islands were located especially toward the shallow headwaters. The scattered return from both high and low frequencies indicated fine-grained water-rich sediments, in agreement with the analysis of soil samples collected 

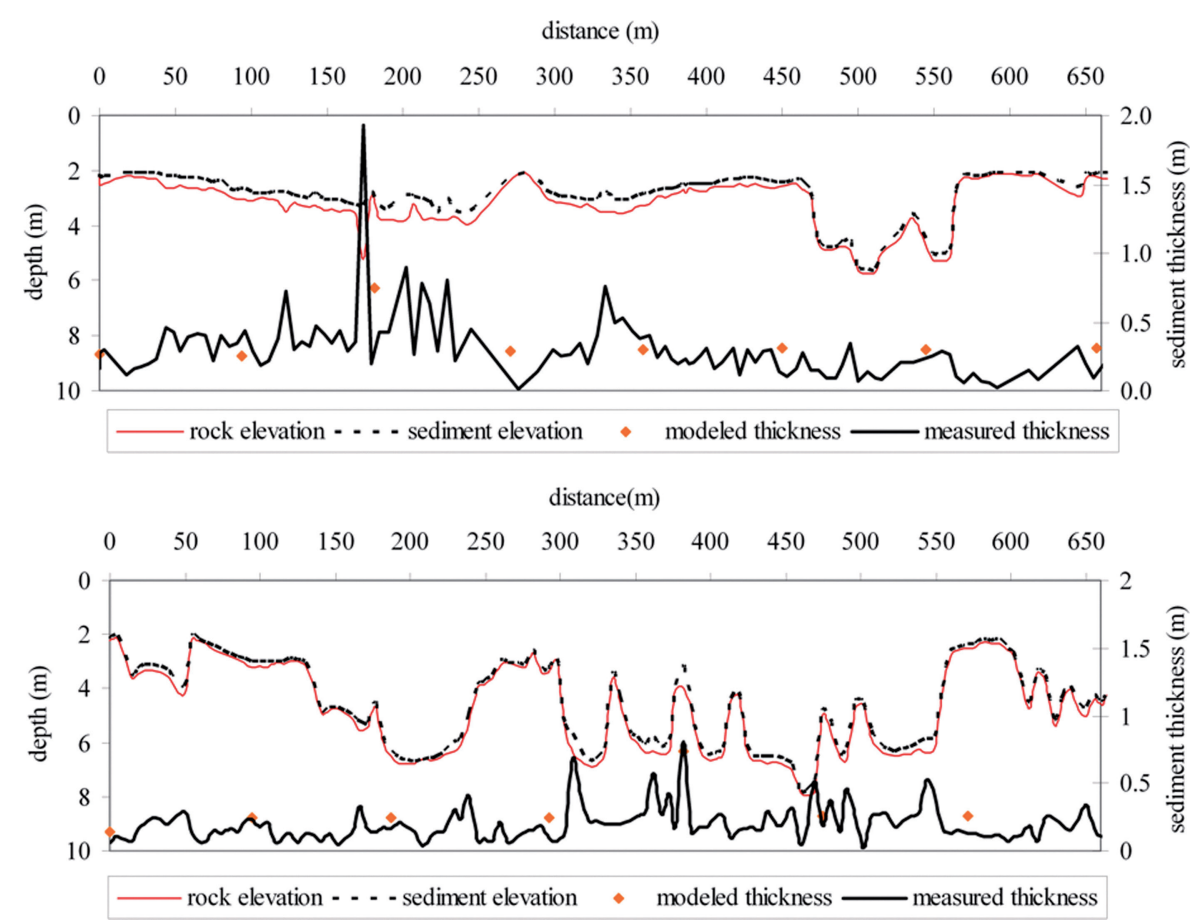

Figure 6.-Topographic profiles and sediment thicknesses along the selected transects. Transect locations shown in Fig.5.

from the lake bottom, where particle size analysis of the samples indicated that the deposited sediments were sandy silt.

For the prediction of lake-wide sedimentation patterns, the EFDC model was applied. Soil loss predicted by USLE was used as input to the hydrodynamic and sediment transport model because long term measurements of sediment concentrations were not available. Simulations considered 2 months, one winter and one summer. The historical analyses of the rainfall data indicated 12 rainy days on average in winter (Dec-Mar), and the input data for runoff were altered accordingly in the model. In summer, streams are usually dry, and the runoff in summer was represented by very low flows. The results of the simulation after 2 months were analyzed (Fig. 7). When the sedimentation results are extrapolated for $9 \mathrm{yr}$, the thickness is calculated about 1.27 $\mathrm{m}$ at deepest regions (close to the river entrances), and the average thickness for the whole lake is estimated as $0.23 \mathrm{~m}$. Due to uncertainties in sediment input data and in the other parameters, the results of our numerical model should be used to estimate the spatial distribution of sediments at the lake bottom and to predict the fate of incoming sediments rather than accepted as a quantitative indicator of sedimentation rates.

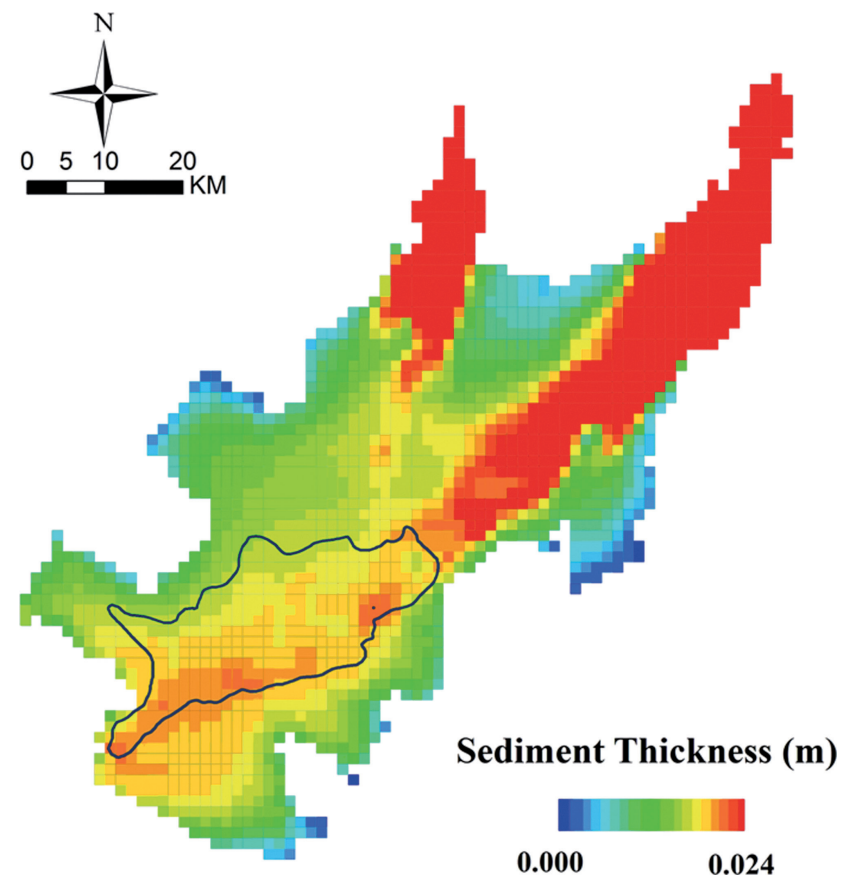

Figure 7.-Sediment thicknesses after 60 days of simulation using data representing both winter (flood) and summer (low flow) conditions. Solid line shows the surveyed area of the lake during the dry period. 
Numerical modeling of the sediment transport within the lake indicated sedimentation patterns useful for future mitigation studies. The numerical model was also used to analyze the effect of flooding-induced sediment deposition at the lake bottom. Results revealed that sediments incoming from the rivers can only be carried to the water intake in flood conditions. When no floods are observed, uniform deposition of sediments throughout the lake, due to initially suspended sediments in the water column, dominated the incoming sediments. Average sediment thickness modeled by the numerical model and derived from dual frequency echo sounder surveys indicated an average thickness of 23 and $25 \mathrm{~cm}$, respectively.

\section{Conclusions}

In this study, sedimentation patterns within the main lake were modeled by a 3-D hydrodynamic and sediment transport model to estimate the spatial distribution of sediments at the lake bottom and to predict the fate of incoming sediments. Due to lack of sediment measurements, a careful application of USLE for the whole watershed composed of 245 polygons was conducted, and sediment input to the model was derived from this analysis. Results of the numerical model indicated that sediments can only be transported to the water intake under flood conditions. During low flow conditions, uniform deposition of sediments throughout the lake due to initially suspended sediments in the water column was observed.

The modeling results were also compared to survey results where a dual frequency $(28 / 200 \mathrm{kHz})$ echo sounder system and GPS were used to surveying the lake. Sediment thickness along the surveyed transects was determined from the difference between high and low frequency readings provided by the echo sounder system. Analysis of sediment cores through use of isotropic signatures of elements is required for accurate identification of sediment layer characteristics at the lake bottom; however, when sediment cores are not available, surveying of reservoir by dual frequency echo sounders provides reasonable estimates for sediment deposition rates. Major uncertainty associated with the depth sounder is the uncertainty of sound speed, which varies with respect to water temperature and type of sediment at the lake bottom. A constant speed of sound was implemented during the surveys resulting in $7 \%$ uncertainty errors.

In addition, readings from an echo sounder should be carefully interpreted at very shallow $(<1 \mathrm{~m})$ depths where multiple echoes from the same bottom surface can be erroneously interpreted as different sediment strata. In addition to these error sources, at sites where aquatic vegetation covers the lake bottom, high frequency readings should not be trusted, and only low frequency readings should be used. The reser- voir survey provided valuable capacity information that can be used for future management.

The sediment volume estimated by EFDC model was compared with the volume of the deposited sediments estimated by USLE, and we observed that only a small portion of the eroded sediments could reach to the deep parts of the lake. The numerical modeling study indicated that most of the sediments had accumulated along the thalwegs close to the river entrances of the lake. Sediment thickness modeled by the numerical model averaged $23 \mathrm{~cm}$ for the surveyed area, comparable with the survey results of $25 \mathrm{~cm}$ average thickness.

\section{Acknowledgments}

Funding for this study is provided from the research grants of Tubitak within the project No: 104Y323 and European Commission project No: 28292 (RESTRAT). We also would like to thank to the staff of Izmir Water and Sewage Authority (IZSU) for their contributions during the collection of data.

\section{References}

Blumberg, A.F., L.A. Khan and J.P. St. John. 1999. Threedimensional hydrodynamic model of New York Habor Region. J. Hydraul. Eng. 125:799-816.

Blumberg, A.F. and G.L. Mellor 1987. A description of a threedimensional coastal ocean circulation model. Chapter 4. P. 1-16. In: Heaps, N.S. (ed.). Three-dimensional coastal and estuarine sciences. American Geophys. Union Geophysical Monograph Board.

Collins, W., R. Gregory and J. Anderson. 1996. A digital approach to seabed classification. Sea Technol. 37(8):83-87.

Çalışkan, A., and S. Elçi. 2008. Effects of selective withdrawal on hydrodynamics of a stratified reservoir. Water Resour. Manage. 23:1257-1273.

Doğan, O. 2002. Türkiye yağışlarının erozyon oluşturma gücü ve üniversal toprak kaybıeşitliğinin yağış erozyon indis değerleri (Erosive potentials of rainfalls in Turkey and erosion index values of universal soil loss equation). General Directorate of Rural Services. Ankara Publications of Training Center Diroctarates Publication Number:220 Report Number:120. Turkish.

Dunbar, J.A., P.D. Higley and S.J. Bennett. 2002. Acoustic imaging of sediment impounded within USDA-NRCS flood control dams. Wisconsin. USDA-ARS National Sedimentation Laboratory Research Report 30.34 pp.

Elçi, S. 2008. Effects of thermal stratification and mixing on reservoir water quality. Limnology 9(2):135-142.

Elçi, S, P. Work, and E.J. Hayter. 2007. Influence of stratification and shoreline erosion on reservoir sedimentation patterns. J. Hydraul. Eng. ASCE. 133(3):255-266.

Falconer, R.A., D.G. George, and P. Hall. 1991. Three-dimensional numerical modelling of wind-driven circulation in a shallow homogenous lake. J. Hydrol. 124:59-79. 
Fan, J. and G. Morris. 1992. Reservoir sedimentation. I: Delta and density current deposits. J. Hydraul. Eng. ASCE. 118(3):354369.

Golson, K.F., T.D. Tsegaye, N.B. Rajbhandari, T.H. Green, and T.L. Coleman. 2000. Evaluating modified rainfall erosivity factors in the Universal Soil Loss Equation. A Symposium on Nutrient Management and Water Quality in the Southern United States: Problems and Solutions Proceedings.

Guy, H.P., D.B. Simons, and E.V. Richardson. 1966. Summary of alluvial channel data from flume experiments, 1956-1961. U.S. Geol. Surv. Prof. Pap. 462-I. 96pp.

Graf, W.H. 1984. Hydraulics of sediment transport. (NY): McGraw-Hill. 513 p.

Hamrick, J.M. 1996. Users manual for the environmental fluid dynamic computer code. College of William and Mary. Virginia Institute of Marine Science. Special Report 328. 224 pp.

Hotchkiss, R.H. and G.Parker. 1991. Shock fitting of aggradational profiles due to backwater. J. Hydraul. Eng. 117(9):11291144.

Jin, K.R., J.M. Hamrick, and T.S. Tisdale. 2000. Application of a three-dimensional hydrodynamic model for Lake Okeechobee. J. Hydraul. Eng. 106:758-772.

Jin, K.R. and Z.G. Ji. 2002. Case study: Modeling of sediment transport and wind-wave impact in Lake Okeechobee. J. Hydraul. Eng. 130:1055-1067.

Jin. K.R., Z.G. Ji, and J.M. Hamrick. 2002. Modeling winter circulation in Lake Okeechobee, Florida. J. Waterw. Port C-ASCE. 128:114-125.

Knudsen Engineering Ltd. 2005. 320B Series echo sounder user manual. by Knudsen Engineering. Limited 10 Industrial Road Perth, ON, Canada.

Lee, S. 2004. Soil erosion assessment and its verification using the universal soil loss equation and geographic information system: A case study at Boun, Korea. Environ. Geol. 45:457465.

McCool, D.K., G.R. Foster, C.K. Mutchler, and L.D. Meyer. 1989. Revised slope length factor for the Universal Soil Loss Equation. Trans. ASAE. 32:1571-1576.

Odhiambo, B.K. and S.K. Boss. 2004. Integrated echo Sounder, GPS, and GIS for reservoir sedimentation studies: Examples from two Arkansas lakes. J. Am. Water Resour. Assoc. Paper: 02061.

Oguz, I., H. Cebel, S. Özden, E. Ayday, and M. Demiryürek. 2006. USLE manual for Turkey, TAGEM-BB-TOPRAKSU 2006/01, Ministry of Agriculture and Rural Affairs, Ankara.

Pratson, L., J. Hughes-Clarke, M. Anderson, T. Gerber, and D. Twichell. 2008. Timing and patterns of basin infilling as documented in Lake Powell during a drought. Geology. 36(11):843-846.

Rueda, F.J. and S.G. Schladow. 2003. Dynamics of large polymictic lake. II:Numerical simulations. J. Hydraul. Eng. ASCE. 129(2):92-101.

Shen, J. and A.Y. Kuo. 1999. Numerical investigation of an estuarine front and its associated topographic eddy. J. Waterw. Port C-ASCE. 125:127-135.

Snyder, N.P., S.A. Wright, C.N. Alpers, L.E. Flint, C.W. Holmes, and D.M. Rubin. 2006. Reconstructing depositional processes and history from reservoir stratigraphy: Englebright Lake, Yuba River, northern California, J. Geophys. Res. 111, F04003.

Soni, J.P. 1981. Laboratory study of aggradation in alluvial channels. J. Hydrol. 49:87-106.

Tetra Tech Inc. 1999. Theoretical and computational aspects of sediment and contaminant transport in the EFDC model. A report to the U.S. Environmental Protection Agency. Tetra Tech, Inc., Fairfax, VA.

Urick, R.J. 1983. Principles of underwater sound. Peninsula Publishing, Los Altos, CA.

Wischmeier, W.H, and D.D. Smith. 1978. Predicting rainfall erosion losses-a guide to conservation planning. U.S. Department of Agriculture, Agriculture Handbook. 537 p.

Yang, C.T. 1996. Sediment transport theory and practice. McGrawHill USA. 396 p.

Yang, Z, A. Baptista and J. Darland. 2000. Numerical modeling of flow characteristics in a rotating annular flume. Dyn. Atmos. Oceans. 31:271-294.

Verstraeten, G. and J. Poesen. 2000. Variability of dry sediment bulk density between and within retention ponds and its impact on the calculation of sediment yields. Earth Surf. Processes. 26:375-394. 